\title{
URGENSI PEMBENTUKAN PERATURAN DESA TENTANG PENGELOLAAN WISATA SYARIAH DALAM MENINGKATKAN KEMANDIRIAN EKONOMI KABUPATEN SUMENEP
}

\author{
Achmad Badarus Syamsi, Adiyono \\ Universitas Trunojoyo Madura \\ Email: badarus.syamsi@trunojoyo.ac.id.
}

\begin{abstract}
Abstrak:
Konsep pariwisata halal diharapkan bisa meningkatkan jumlah wisman di objekobjek wisata tersebut. Konsep pariwisata halal diambil karena dilihat dari sisi sosial budaya agama masyarakatnya, banyaknya pondok pesantren, obyek wisata religi, dan kesenian Islam. Disisi lain Kepastian hukum merupakan hal yang sangat urgen untuk menarik minat investor dan wisatawan. Disinilah urgensi dari keberadaan legalitas pariwisata halal. Tujuan dari Penelitian ini pertama adalah untuk mengemukakan bentuk pengaturan pariwisata halal yang sudah diterapkan di beberapa daerah di Indonesia. Kedua akan berupaya untuk menemukan model pengaturan yang efektif, efisien dan mempunyai kepastian hukum yang tinggi untuk diterapkan di Sumenep. Penelitian ini merupakan penelitian pustaka dengan pendekatan kualitatif deskriptif, yang berusaha untuk memaparkan tujuan penelitian di atas. Sumber data yang digunakan adalah ketentuan mengenai pembuatan peraturan perundang-undangan dan peraturan pariwisata halal di Indonesia. Adapun hasil dari penelitian ini adalah penemuan sebuah model atau bentuk peraturan tentang pariwisata halal di Sumenep yang efektif, efisien dan mempunyai kepastian hukum yang tinggi.
\end{abstract}

Kata Kunci: legalitas, pariwisata halal, prinsip syariah

\begin{abstract}
:
The concept of halal tourism is expected to increase the number of foreign tourists in these tourist objects. The concept of halal tourism is taken because it is seen from the socio-cultural side of the community, the number of Islamic boarding schools, religious tourism objects, and Islamic arts. This is where the urgency of the legality of halal tourism. The purpose of this research The first is to give shape halal tourism arrangement that has been applied in several regions in Indonesia. Both will attempt to find a model setting of effectif eficient and have a high supremacy of law to be applied in Sumenep. This research is a literature research with a qualitative deskriptif approach, that seeks to explain the purpose of its research. The sources data that used is provisions about rule making and regulations halal tourism in Indonesia. The resault of this research is discovery of a model or form regulations on tourism kosher in Sumenep effective, efficient and have a high supremacy of law.
\end{abstract}

Keywords: legality, halal tourism, sharia principles. 


\section{Pendahuluan}

Kabupaten Sumenep merupakan salah satu kabupaten yang berada di pulau Madura Propinsi Jawa Timur. Letak geografis kabupaten Sumenep berada di ujung timur pulau Madura. Terdapat 27 kecamatan, yang terbagi dalam 19 kecamatan daratan dan 8 kecamatan kepulauan. Sumber daya alam di wilayah kabupaten Sumenep sangat melimpah dan beraneka ragam. Salah satunya adalah wisata alam yang mempunyai potensi yang luar biasa, sebagai bukti pada tahun 2019 obyek wisata pantai Gili Labak memperoleh penghargaan Anugerah Wisata Jawa Timur sebagai terbaik kedua untuk kategori daya tarik wisata alam. ${ }^{1}$ Selain Gili Labak, kabupaten Sumenep juga memiliki satu obyek wisata yang juga sangat menarik untuk dikunjungi, yaitu Gili Iyang. Sebuah pulau yang memiliki kadar oksigen terbaik kedua di dunia. ${ }^{2}$

Mayoritas masyarakat Sumenep beragama Islam. Keberagamaan di masyarakat Sumenep sangat dijunjung tinggi, sehingga sampai mengakar ke dalam budaya kemasyarakatan. Hal tersebut salah satunya dapat ditunjukkan dengan tradisi yang bersifat rutinan seperti acara yang diselenggarakan setiap malam Jum'at. Selain itu juga dapat dilihat dari penghormatan yang tinggi kepada seorang tokoh agama atau kyai. Bahkan dalam bermasyarakat peran kyai tidak hanya sebagai seorang ahli agama, melainkan juga menjadi rujukan dalam semua sisi permasalahan di masyarakat, termasuk dimintai pertimbangan dan dukungan dalam berpolitik. ${ }^{3}$

Dua hal di atas, wisata alam dan keberagamaan yang kuat, sebuah kekayaan yang potensial dan bisa membawa kabupaten Sumenep dikenal oleh dunia. Apalagi pada tahun 2019 Indonesia menjadi negara nomor satu di dunia yang paling banyak dikunjungi oleh para wisatawan muslim dari seluruh penjuru dunia. ${ }^{4}$ Untuk bisa mewujudkan hal tersebut yang perlu dilakukan adalah dengan menetapkan konsep pariwisata syariah atau halal tourism.

Wacana dan rencana terkait penetapan obyek wisata berprinsip syariah di kabupaten Sumenep sudah lama mengemuka. Pada tahun 2014 Bupati Sumenep memaparkan bahwa pariwisata syariah sudah menjadi trend dunia dan menarik investor. ${ }^{5}$ Pada tahun 2017 MUI, sebagai sebuah lembaga yang menaungi para tokoh agama, menyampaikan sudah memiliki pedoman pariwisata syariah. ${ }^{6}$ Bahkan pada tahun 2018, bupati Sumenep mendukung MES (Masyarakat Ekonomi Syariah) untuk mengembangkan wisata syariah di Sumenep. ${ }^{7}$

Selain itu terkait dengan ketentuan kepariwisataan Pemerintah Daerah Propinsi Jawa timur mengeluarkan Peraturan daerah Nomor 6 Tahun 2017 tentang

\footnotetext{
${ }^{1}$ http://www.sumenepkab.go.id/berita/baca/wisata-pulau-gili-labak-terbaik-kedua-di-awj-2019, diakses pada tanggal 23 Mei 2020.

2 Pemda Kab. Sumenep, 2018, Buku 1 Masterplan Smart City, Kabupaten Sumenep 2019-2028, 15

${ }^{3} \mathrm{Ibid}, 12-13$

${ }^{4}$ Mastercard-CrescentRating Global Muslim Travel Index (GMTI) report 2019, 29

${ }^{5}$ http://sumenepkab.go.id/berita/baca/potensi-wisata-syariah-sudah-menjadi-trend-dunia, diakses pada tanggal 23 Mei 2020.

6 https://mediamadura.com/2017/03/06/mui-sumenep-ternyata-sudah-miliki-pedomanpariwisata-syariah/d diakses pada tanggal 23 Mei 2020.

${ }^{7}$ http://www.ekonomisyariah.org/id/6956/wisata-syariah-potensi-lokal-yang-siapdikembangkan-mes-sumenep/, diakses pada tanggal 23 Mei 2020.
} 
Rencana Induk Pembangunan Kepariwisataan Provinsi Jawa Timur Tahun 20172032. Dalam lampiran tersebut disebutkan bahwa Madura sebagai salah satu destinasi pariwisata provinsi (DPP) Jawa Timur yang mengusung konsep wisata halal dan wisata bahari. ${ }^{8}$

Berdasarkan ketentuan Perda Propinsi Jawa Timur di atas yang mengatur mengenai konsep wisata halal Madura, sudah semestinya daerah-daerah yang berada di pulau Madura membuat peraturan daerah tentang kepariwisataan yang mengususng konsep wisata halal. Sebagaimana hal tersebut di atas bahwa ketentuan mengenai penyusunan atau pembentukan Peraturan Daerah Provinsi berlaku secara mutatis mutandis terhadap penyusunan Peraturan Daerah Kabupaten/Kota. Hal ini sesuai dengan ketentuan pasal 63 Undang-undang Nomor 12 Tahun 2011 tentang Pembentukan Peraturan Perundang-undangan yang menegaskan bahwa: "Ketentuan mengenai penyusunan Peraturan Daerah Provinsi sebagaimana dimaksud dalam Pasal 56 sampai dengan Pasal 62 berlaku secara mutatis mutandis terhadap penyusunan Peraturan Daerah Kabupaten/Kota."

Namun, sampai tahun 2020 pemerintah daerah Kabupaten Sumenep belum juga mengeluarkan perda terkait pengelolaan pariwisata syariah. Maka agar pengelolaan wisata syariah dapat berjalan dan mendapat payung hukum perlu untuk melakukan terobosan di bidang hukum, yaitu dengan menyusun peraturan desa. Keberadaan peraturan desa tentang pengelolaan wisata syariah nantinya diharapkan dapat menjadikan desa tersebut memiliki kemandirian ekonomi. Beberapa desa di Indonesia sudah membuktikan hal tersebut, bahkan beberapa desa kaya di Indonesia mendapatkan penghasilan dari wisata, antara lain yaitu desa Ponggok di kabupaten Klaten, desa Kutuh kabupaten Badung, desa Bleberan kabupaten Gunungkidul. ${ }^{9}$ Hal inilah yang membuat penulis tertarik untuk meneliti urgensitas peraturan desa tentang pengelolaan pariwisata syariah dan kemandirian ekonomi masyarakat kabupaten Sumenep.

Berdasarkan latar belakang di atas permasalahan yang akan dibahas yaitu mengenai urgensi peraturan desa dalam memberikan kepastian hukum baik bagi investor maupun wisatawan. Hal itu dapat diketahui dengan mengkaji beberapa hal. Pertama, pengaturan tentang pengelolaan pariwisata di kabupaten Sumenep. Kedua, legalitas atau kedudukan peraturan desa dalam sisten hukum di Indonesia. Ketiga, respons pemangku jabatan dan masyarakat pelaku wisata di kabupaten Sumenep terkait peraturan desa tentang pengelolaan wisata syariah.

\section{Metode Penelitian}

Penelitian ini adalah field research yang bersifat deskriptif kualitatif. Penelitian ini termasuk penelitian hukum empiris atau disebut juga penelitian hukum sosiologis (socio legal research) yang menitikberatkan terhadap kerjanya hukum di masyarakat, ${ }^{10}$ yaitu mengenai bentuk peraturan perundang-undangan yang dapat melindungi secara efektif para investor dan wiatawan. Pada penelitian ini, data

\footnotetext{
${ }^{8}$ Lampiran II mengenai Peta Perwilayahan Pembangunan Destinasi Wisata dalam Peraturan Daerah Provinsi Jawa Timur Nomor 6 Tahun 2017.

${ }^{9}$ https://www.medcom.id/nasional/daerah/ObzqOBeN-sepuluh-desa-dianggap-paling-suksesmanfaatkan-dana-desa, diakses pada tanggal 23 Mei 2020

10 Bambang Sunggono, Metodologi Penelitian Hukum (Jakarta: PT Raja Grafindo Persada, 1998), 43.
} 
primer diperoleh melalui pengisian kuisioner oleh responden secara langsung serta melalui hasil wawancara secara depth interview, berikut adalah datanya : Dinas Pariwisata kabupaten Sumenep, masyarakat yang terkait langsung dengan objek wisata, misalnya pengelola objek wisata. Setelah data dikumpulkan kemudian diolah dan dianalisa dengan analisa kualitatif dengan logika induktif. Pola berpikir induktif ini untuk menganalisis data-data yang bersifat khusus untuk ditarik kepada yang umum, yaitu identifikasi peraturan daerah tentang pengelolaan pariwisata, respons masyarakat dan dinas pariwisata dalam penyusunan peraturan daerah tentang pengelolaan pariwisata di Madura yang berkonsep pariwisata halal. Kemudian dari hasil analisa data yang diperoleh dideskripsikan secara urut dan teliti sesuai dengan permasalahan yang dikaji.

\section{Pembahasan dan Hasil Penelitian Sistem Hukum di Indonesia}

Negara Indonesia adalah negara hukum (rechstaat). Hal tersebut termaktub dalam konstitusi Republik Indonesia yaitu pasal 1 ayat (3) Undang-undang Dasar 1945. Dalam sejarah terapat dua istilah yang sangat umum di dunia hukum untuk ide sebuah negara yang berdasarkan atas hukum, yaitu "Rechtstaat" yang berkembang di negara-negara civil law dan "The Rule Of law" yang berkembang di United Kingdom dan negara-negara common law. ${ }^{11}$

Mochtar Kusumaatmadja menjelaskan bahwa negara hukum: ${ }^{12}$

“ ...negara yang berdasarkan hukum, dimana kekuasaan tunduk pada hukum dan semua orang sama dihadapan hukum ". Dalam UUD 1945 "Rechtstaat" diterjemahkan sebagai negara berdasar atas hukum, yang berarti bahwa fungsi peraturan perundang-undangan tidak hanya sebatas produk negara dibidang pengaturan, namun juga memberi bentuk pada nilai-nilai dan norma-norma yang berlaku dan hidup dalam masyarakat. A. Hamid Attamini, berpendapat "peraturan perundang-undangan adalah salah satu metode dan instrument ampuh yang tersedia untuk mengatur dan mengarahkan kehidupan masyarakat menuju cita-cita yang diharapkan."13

Syarat-syarat yang harus dipenuhi dalam suatu negara hukum sebagaimana dikemukakan oleh Burkens seperti dikutip oleh Philipus M. Hadjon dalam tulisannya adalah $:^{14}$

"Asas Legalitas: setiap tindak pemerintahan harus didasarkan atas dasar Peraturan Perundang-Undangan (Wetterlijke Grondslag). Dengan landasan ini, Undang-Undang dalam arti formal dan UUD sendiri merupakan tumpuan dasar tindak pemerintahan.

Pembagian Kekuasaan: syarat ini mengandung makna bahwa kekuasaan Negara tidak bertumpu pada satu tangan.

\footnotetext{
${ }^{11}$ Maria Farida Indrati Soeprapto. Tahun 2006. Ilmu Perundang-Undangan, Penerbit Kanisius. 102

12 Mochtar Kusumaatmadja. 1995. " Pemantapan Cita Hukum dan Asas-Asas Hukum Nasional di Masa Kini dan Masa Yang Akan Datang, Makalah Jakarta. 1

${ }^{13}$ A. Hamid Attamini. 1992. Teori Perundang-Undangan Indonesia, Pidato Pengukuhann Jabatan Guru Besar Tetap Fakultas Hukum UI. 8

${ }^{14}$ Philipus M. Hadjon. 1994. Ide Negara Hukum dalam Sistem Ketatanegaraan Republik Indonesia, makalah. 4
} 
Hak-Hak Dasar (Grondrechten): Hak-hak Dasar merupakan sasaran perlindungan hokum bagi rakyat dan sekaligus membatasi kekuasaan pembentukan Undang-Undang.

Pengawasan Pengadilan: Bagi rakyat tersedia saluran melalui Pengadilan yang bebas untuk menguji keabsahan tindakpemerintahan (rechtmatigheids toetsing)."

Keberlakuan suatu peraturan perundang-undangan mempunyai lingkuan keberlakuan yang disebut dengan istilah lingkungan kuasa. Lingkungan Kuasa suatu aturuan hukum Menurut Logemann meliputi empat hal, yaitu: ${ }^{15}$

"Pertama, Lingkungan kuasa tempat (ruimtegebied atau territorial sphere). Berlakunya aturan hukum (peraturan perundang-undangan) dibatasi oleh ruang atau tempat. Apakah sesuatu aturan hukum itu berlaku untuk suatu wilayah negara atau hanya berlaku untuk suatu bagian dari wilayah negara. Seperti diketahui, "daerah kekuasaan" berlakunya suatu Undang-undang dapat meliputi seluruh wilayah negara, tetapi untuk suatu keadaan tertentu atau suatu materi tertentu hanya diberlakukan untuk suatu wilayah tertentu pula. Suatu peraturan daerah hanya berlaku untuk suatu daerah tertentu (Provinsi, dan Kabupaten/Kabupaten) saja.

Kedua, Lingkungan kuasa persoalan (zakengebied atau material sphere). Suatu materi atau persoalan tertentu yang diatur dalam suatu peraturan perudangundangan mengidentifikasi masalah tertentu. Dengan demikian maka persoalan yang diatur dalam peraturan perundang-undangan menunjukkan lingkup materi yang diatur, apakah persoalannya adalah persoalan publik atau privat, persoalan perdata atau pidana dsb. Materi tersebut menunjukkan lingkup masalah atau persoalan yang diatur.

Ketiga, Lingkungan kuasa orang (personengebied). Sesuatu aturan mungkin hanya diberlakukan bagi sekelompok atau segolongan orang atau penduduk tertentu. Dengan ditetapkannya subyek atau orang (orang) tertentu dalam peraturan perundangundangan tersebut maka memperlihatkan adanya pembatasan mengenai orangnya. Undang-undang tentang Pegawai Negeri, Undangundang tentang Tenaga Kerja. Undangundang tentang Pidana Militer, Undangundang tentang Pajak Orang Asing,dsb; menunjukkan bahwa peraturan perundangundangan tersebut hanya diberlakukan bagi kelompak orang yang diidenrifikasi dalam peraturan perundang-undangan tersebut.

Keempat, Lingkungan kuasa waktu (tijdsgebied atau temporal sphere). Lingkungan waktu menunjukkan kapan suatu peraturan perundana-undangan berlaku, apakah beriaku untuk suatu masa tertentu atau untuk masa tidak tertentu. Apakah mulai berlaku sejak ditetapkan atau berlaku surut sebelum ditetapkan. Berlakunya suatu peraturan hukum ditentukan oleh waktu."

Dalam teori tata urutan atau hirarki peraturan perundang-undangan sebagairnana dikemukakan oleh Hans Kelsen, terdapat asas-asas atau prinsipprinsip tata urutan, yaitu ${ }^{16}$ Perundang-undangan yang rendah derajatnya tidak dapat mengubah atau mengenyampingkan ketentuan-ketentuan

${ }_{15}$ Ranggawijaya Rosidi. 1998. Pengantar Ilmu perundang-Undangan Indonesia, Penerbit Mandar Maju, Bandung. 98.

16 Ibid. 
perundangundangan yang lebih tinggi; Perundang-undangan hanya dapat dicabut, diubah atau ditambah oleh atau dengan perundang-undangan yang sederajat atau yang lebih tinggi tingkatannya; Ketentuan-ketentuan perundang-undangan yang lebih rendah tingkatannya tidak mempunyai kekuatan hukum dan tidak mengikat apabila bertentangan dengan perundang-undangan yang lebih tinggi tingkatannya. Sebaliknya ketentuan-ketentuan perundang-undangan yang lebih tinggi, tetap berlaku dan mempunyai kekuatan hukum serta mengikat, walaupun diubah, ditambah, diganti atau dicabut oleh peraturan perundang-undangan yang lebih rendah; Materi yang seharusnya diatur oleh perundang-undangan yang lebih tinggi tingkatannya tidak dapat diatur oleh perundng-undangan yang lebih rendah;

Hierarki peraturan perundang-undangan di Indonesia yang berlaku saat ini adalah Undang-Undang Nomor 12 tahun 2011 tentang Pembentukan Peraturan perundang-undangan. Namun perlu diketahui juga bahwa sebelumnya juga terdapat beberapa ketentuan yang pernah berlaku terkait pembentukan peraturan perundang-undangan, dan paling tidak sudah mengalami empat kali perubahan yaitu;

Pertama, Susunan hierarki dalam Ketetapan MPRS Nomor XX/MPRS/1966 tentang Momorandum DPR-GR mengenai Sumber Tertib Hukum Republik Indonesia dan Tata Urutan Peraturan Perundang-Undangan Republik Indonesia, sebagai berikut : pertama, Undang-Undang Dasar 1945. Kedua, Ketetapan Majelis Pemusyarawatan Rakyat. Ketiga, Undang-Undang Peraturan Pemerintah Pengganti Undang-Undang. Keempat, Peraturan Pemerintah. Kelima, Keputusan Presiden. Keenam, Peraturan-Peraturan Pelaksana Lainnya seperti Peraturan Menteri dan Intruksi Menteri.

Kedua, Sususan hierarki dalam Ketetapan MPR RI Nomor III/MPR/2000 tentang Sumber Hukum dan Tata Urutan Peraturan Perundang-undangan, sebagai berikut : pertama, Undang-Undang Dasar 1945. Kedua, Ketetapan Majelis Pemusyarawatan Rakyat. Ketiga, Undang-Undang. Keempat, Peraturan Pemerintah Pengganti Undang-Undang. Kelima, Peraturan Pemerintah. Keenam, Keputusan Presiden. Ketujuh, Peraturan Daerah.

Ketiga, Susunan Hierarki dalam Undang-Undang Nomor 10 Tahun 2004 tentang Pembentukan Peraturan Perundang-Undangan, sebagai berikut : pertama, Undang-Undang Dasar 1945. Kedua, Undang-Undang/ Peraturan Pemerintah Pengganti Undang-Undang. Ketiga, Peraturan Pemerintah. Keempat, Peraturan Presiden. Kelima, Peraturan Daerah, meliputi Peraturan daerah Provinsi dibuat oleh DPRD bersama Gubernur, Peraturan daerah kabupaten/Kota dibuat oleh DPRD Kabupaten/Kota bersama dengan Bupati/Walikota, Peraturan Desa/Peraturan yang setingkat, dibuat oleh badan perwakilan desa atau nama lainnya bersama dengan kepala desa atau nama lainnya.

Keempat, Susunan hierarki dalam Undang-Undang Nomor 12 Tahun 2011 tentang Pembentukan Peraturan Perundang-Undangan, sebagai berikut : pertama, Undang-Undang Dasar 1945. Kedua, Ketetapan Majelis Pemusyawaratan Rakyat. Ketiga, Undang-Undang/Peraturan Pemerintah Pengganti Undang-Undang. Keempat, Peraturan Pemerintah. Kelima, Peraturan Presiden. Keenam, Peraturan daerah Provinsi. Ketujuh, Peraturan daerah kabupaten/Kota.

a. Undang-Undang Dasar 1945 
b. Ketetapan Majelis Pemusyawaratan Rakyat

c. Undang-undang/ Peraturan Pemerintah pengganti Undang-Undang

d. Peraturan Pemerintah

e. Peraturan Presiden

f. Peraturan daerah Provinsi

g. Peraturan Daerah kabupaten/Kota.

\section{Pariwisata syariah}

Berwisata merupakan salah satu perbuatan yang dihukumi berdasarkan niatnya. Maksudnya apabila niatnya adalah untuk kewajiban, maka wajib melakukannya, seperti pergi ke Mekkah untuk menunaikan ibadah haji bagi yang belum pernah menunaikannya. ${ }^{17} \mathrm{Hal}$ ini sebagaimana yang dimaksud sebuah kaidah fikih, "segala perkara tergantuang pada niat dan tujuannya". Pada dasarnya salah satu manfaat keberadaan pariwisata adalah untuk mengantarkan keyakinan atau iman para wisatawan muslim agar semakin kokoh dan mantap dengan banyak merenungi ciptaan Tuhan yang sedemikian melimpah dan bervariasi, baik keanekaragaman manusia maupun alam semesta, seperti flora, fauna dan lingkungan dimana mereka tinggal. Semuanya itu dapat dinikmati dan diperoleh oleh para wisatawan melalui pariwisata. ${ }^{18}$

Berkaitan dengan peraturan terdapat dua macam hukum yang harus ditaati oleh masyarakat secara bersamaan. Pertama, sebagai warga negara wajib taat terhadap ketentuan hukum negara di mana mereka tinggal. Kedua, sebagai pemeluk sebuah agama, dalam hal ini adalah seorang Muslim, mereka wajib mengikuti ketentuan-ketentuan agama Islam. Implementasi kedua hukum itu, juga berlaku bagi pemimpin, para enterpreneur, maupun masyarakat stakeholders pariwisata. Pada prinsipnya mereka, equal before of law, sama di hadapan undang-undang. Maksudnya tidak ada diskriminasi atau tebang pilih antara satu pihak dengan yang lain.

Beberapa ketentuan dalam kaitan dengan destinasi wisata yang sesuai dengan prinsip syariah akan dikemukakan sebagai berikut. Pertama, tujuan wisata wajib diarahkan pada usaha untuk mewujudkan kemaslahatan dan kebaikan baik bagi individu pribadi maupun secara umum. Dampak positif yang diperoleh secara pribadi yaitu munculnya pencerahan, penyegaran dan penenangan jiwa dan pikiran. Adapun secara umum adalah dengan memelihara amanah yang tercermin dengan memelihara kebersihan, kelestarian alam, sanitasi dan lingkungan; keamanan dan kenyamanan; serta terwujudnya sebuah sikap penghormatan terhadap nilai-nilai akhlak dan kearifan lokal. Kedua, berkaitan dengan sarana prasarana, dalam wilayah sebuah obyek wisata wajib mempunyai tempat ibadah yang mudah dijangkau dan layak pakai serta sesuai dengan ketentuan Islam. Ketiga, terkait dengan larangan-larangan destinasi wajib terhindar dari: perilaku kemusyrikan dan khurafat; maksiat, pornografi, zina, narkoba dan judi, minuman keras, pertunjukan

\footnotetext{
${ }^{17}$ Fahad Salim Bahammam, Panduan Wisatawan Muslim, terj. Ganna Pryadarizal Anaedi \& Syifa Annisa (Jakarta: Pustaka Al-Kautsar, 2012), 9.

18 Muhammad Djakfar, Pariwisata Halal: Perspektif Multidimensi (Malang: UIN Maliki Press, 2017), 179.
} 
seni dan budaya serta atraksi yang tidak sesuai dengan ketentuan-ketentuan dalam agama Islam. ${ }^{19}$

\section{Kemandirian Ekonomi}

Secara etimologi kemandirian adalah hal atau keadaan dapat berdiri sendiri tanpa bergantung pada orang lain. ${ }^{20}$ Kemandirian merupakan sebuah konsep yang serng dihubungkan dengan pembangunan dan pemberdayaan masyarakat. Program-program pembangunan dan pemberdayaan dalam konsep ini dirancang secara sistematis agar individu ataupun masyarakat menjadi subyek dari pemberdayaan tersebut. Nilai-nilai kemandirian yang dimiliki individu akan menjadi sempurna apabila didukung oleh sifat-sifat kemandirian yang meliputi: mandiri psikososial, kultural dan ekonomi, disiplin prakarsa dan wirausaha, kepemimpinan dan orientasi dalam persaingan. ${ }^{21}$ Pada konteks dunia kerja mandiri atau kemandirian muncul sering dengan berkembangnya orientasi kerja, yang mengarah pada sikap wirausaha atau wiraswasta. Perilaku mandiri merupakan fundamen dasar seseorang dalam meningkatkan kualitas kerja dalam pekerjaannya. ${ }^{22}$

Jiwa mandiri tumbuh dan berkembang seiring dengan tumbuhnya konsep wiraswasta atau dikenal istilah lain yaktni wirausaha atau kewirausahaan, atau istilah lain yang disebut dengan makarya. Seorang pengusaha harus memiliki jiwa kemandirian, dalam hal ini jiwa enterpreneurship ditentukan oleh tiga komponen utama yang ada dalam diri seseorang yakni kemauan, ketekunan dan keuletan. ${ }^{23}$

Menurut Stienberg tiga aspek kemandirian yaitu kemandirian emosi (emotional autonomy), kemandirian perilaku (behavioral autonomy) dan kemandirian nilai (values autonomy). Kemandirian perilaku merupakan kemampuan individu dalam menentukan pilihan atau keputusan untuk mengelola dirinya. ${ }^{24}$ Ada tiga domain kemandirian perilaku menurut Stienberg, yaitu; a) memiliki kemampuan mengambil keputusan yang ditandai oleh menyadari adanya resiko dari tingkah lakunya, memilih alternatif pemecahan masalah didasarkan atas petimbangan sendiri dan orang lain, bertanggung jawab atas konsekunensi dari keputusan yang diambilnya; b) memiliki kekuatan terhadap pengaruh pihak lain yang ditandai oleh tidak mudahnya terpengaruh tekanan teman sebaya dan orang tua dalam mengambil keputusan, memasuki kelompok sosial tanpa tekanan; c) memiliki rasa percaya diri (self-reliance) yang ditandai dengan merasa mampu memenuhi kebutuhan sehari-hari, merasa mampu memenuhi tanggung jawab,

\footnotetext{
19 Fatwa Dewan Syariah Nasional Mejelis Ulama Indonesia N0.108/DSN-MUI/X/2016 tentang Pedoman Penyelenggaraan Pariwisata Berdasarkan Prinsip Syariah.

20 https://kbbi.kemdikbud.go.id/entri/nul

21 Moh Wardi, Pengembangan entrepreneurship berbasis experiential learning di pesantren Al-Amien Prenduan Sumenep dan Darul Ulum Banyuanyar Pamekasan. Diss. UIN Sunan Ampel Surabaya, 2017.

22 M. Kamil. 2008. Pusat Budaya dan Belajar Masyarakat. Bandung: Dewa Ruchi. 135

${ }^{23}$ Soetomo. 2006. Strategi-strategi Pembangunan Masyarakat. Yogyakarta: Pustaka Pelajar. 42

24 L. Steinberg. 1999. Adolescence (6th edition). New York: McGraw Hill. 289
} 
merasa mampu mengatasi sendiri masalah yang dihadapi dan berani mengemukakan ide atau gagasan. ${ }^{25}$

Kemandirian ekonomi telah menjadi suatu keniscayaan atau tuntutan yang harus segera diwujudkan. Ketergantungan pada pihak luar akan selalau menjadi penyebab seseorang atau keluarga tersebut tidak menjadi mandiri dalam perekonomian keluarganya. ${ }^{26}$ Menurut Avilliani kemandirian ekonomi diartikan sebagai bangsa, masyarakat ataupun keluarga yang memiliki ketahanan ekonomi terhadap berbagai macam krisis dan tidak tergantung pada pihak luar. Seseorang ataupun kelompok dikatakan akan memiliki jati diri dan karakter yang kuat apabila memiliki kemandirian ekonomi. ${ }^{27}$

\section{Analisa}

Pengambilan data yang digunakan adalah dengan melakukan wawancara terhadap dinas pariwisata dan pengelola wisata. Adapun wisata yang termasuk dalam kategori penelitian ini adalah wisata yang dikelola oleh desa. Di kabupaten Sumenep wisata yang dikelola oleh desa adalah wisata Pantai Sembilan. ${ }^{28}$ Secara umum terdapat dua peraturan daerah yang menjadi dasar hukum pariwisata di Kabupaten Sumenep, yaitu Peraturan Daerah Kabupaten Sumenep Nomor 12 Tahun 2013 tentang Rencana Tata Ruang Wilayah Kabupaten Sumenep Tahun 2013-2033 dan Peraturan Bupati Sumenep Nomor 54 Tahun 2018 tentang Kedudukan, Susunan Organisasi, Tugas Fungsi Dan Tata Kerja Unit Pelaksana Teknis Daerah Pada Dinas Pariwisata, Kebudayaan, Pemuda Dan Olah Raga Kabupaten Sumenep.

Menurut Undang-undang No.6 tahun 2014 Tentang Desa, bahwa desa diberikan kebebasan untuk mengelola desanya. Wisata merupakan salah satu yang dibebaskan pengelolaannya oleh undang-undang untuk dikelola desa agar memberikan kontribusi bagi desa itu sendiri dan juga daerah setempat, baik dari segi ekonomi dan kesejahteraan lainnya.

Pengembangan ekonomi lokal desa menurut pasal 18 UU Nomor 6 tahun 2014 meliputi, Pembangunan dan pengelolaan tempat umum yang ada di Desa, hal ini berarti juga lahan yang akan dijadikan objek wisata. Yang kedua yaitupengembangan usaha mikro berbasis desa, salah satu caranya dengan memanfaatkan pasar desa, Pendayagunaan keuangan mikro berbasis desa dengan cara membentuk kopersi desa, Penetapan komoditas unggulan pertanian dan perikanan desa dengan cara memnfaatkkan kondisi geografis desa dan lahan pertanian desa, dan Pendirian pengelolaan BUMDesa dan Pemanfaatan sumber daya alam dan lingkungan desa.

Bagi desa yang memiliki objek wisata yang menarik dapat menggunakan dana desa dalam mengembangkan potensi wisata desa Pemerintah Desa Kabupaten Sumenep. Adanya objek wisata tentunya memiliki dampak bagi masyarakat sekitar,

\footnotetext{
25 Ibid. 292

${ }^{26}$ Wardi, Moh, et al. "Entrepreneurship and Financing In Islamic Educational Institution Of Darul Ulum Banyuanyar Pamekasan." Academy of Entrepreneurship Journal 25 (2019): 1-14.

27 Avilliani. (2012). Kemandirian Ekonomi. UIN: Institute for Development of Economics and Finance (INDEF). 6

28 Wawancara dengan Pak Sam, dinas pariwisata Kabupaten Sumenep
} 
baik dari perilaku masyarakat maupun kesejahteraan ekonominya. Perubahan perilaku yang nampak bagi masyarakat sekitar objek wisata yaitu gaya hidup yang mulai terkontaminasi para wisatawan.

Sedangkan kesejahteraan ekonominya yaitu adanya peluang kerja baru masyarakat seperti pemandu wisata, pemilik transportasi umum, jasa toilet umum, penjual aneka makanan, oleh-oleh dan souvenir. Jika dilihat dari banyaknya dampak parsial yang disebabkan oleh suatu objek wisata, semestinya objek wisata akan menyumbangkan banyak pendapatan kepada daerah. Namun hal ini akan menjadi sebaliknya jika pemerintah daerah mengabaikan perkembangan wisata yang ada di daerahnya. ${ }^{29}$

Pantai 9 (Pantai sembilan) merupakan objek wisata baru yang ada di kabupaten sumenep. Pantai 9 terletak di kepulauan gili genting tepatnya di desa bringsang kecamatan gili genting, salah satu pulau yang dimiliki oleh Kabupaten Sumenep. Pantai tersebut masih dalam tahap pengembangan, wisatawan lokal dari daerah Sumenep sendiri sudah banyak yang mengetahui lokasi wisata tersebut, akses transportasi menuju pulau gili genting juga sangat mudah, karena disana sudah padat penduduk.

Secara prinsip pihak dinas pariwisata Sumenep mendukung konsep pariwisata syariah, namun di sisi lain pihak yang harus mendukung dan mensepakati agar konsep tersebut berjalan adalah para tokoh masyarakat di Sumenep. Berdasarkan keterangan dari pengelola wisata kurang sependapat terkait branding pariwisata syariah. Penyematan nama syariah menjadi sesuatu hal yang lebih bersifat ibadah yang seharusnya dipisahkan dengan konsep wisata, karena hal tersebut dua hal yang berbeda. Secara praktik pengelolaan yang mereka jalankan tidak bertentangan dengan syariah dan itu cukup bagi mereka tanpa harus ada nama syariah dalam branding-nya. Mereka lebih setuju menyebutnya dengan wisata berkearifan lokal. Karena data di lapangan menunjukkan mayoritas beragama Islam dan memegang teguh ajaran agama Islam dalam kehidupan sehari-hari. ${ }^{30}$

\section{Penutup}

Terdapat dua peraturan daerah yang menjadi dasar hukum pariwisata di Kabupaten Sumenep, yaitu Peraturan Daerah Kabupaten Sumenep Nomor 12 Tahun 2013 tentang Rencana Tata Ruang Wilayah Kabupaten Sumenep Tahun 2013-2033 dan Peraturan Bupati Sumenep Nomor 54 Tahun 2018 tentang Kedudukan, Susunan Organisasi, Tugas Fungsi Dan Tata Kerja Unit Pelaksana Teknis Daerah Pada Dinas Pariwisata, Kebudayaan, Pemuda Dan Olah Raga Kabupaten Sumenep.

Menurut Undang-undang No.6 tahun 2014 Tentang Desa, bahwa desa diberikan kebebasan untuk mengelola desanya. Wisata merupakan salah satu yang dibebaskan pengelolaannya oleh undang-undang untuk dikelola desa agar memberikan kontribusi bagi desa itu sendiri dan juga daerah setempat, baik dari segi ekonomi dan kesejahteraan lainnya.

${ }^{29}$ Aziz, A., \& Wardi, M. (2020, April). The Use of Information Technology among Journalists in Madura: WhatsApp applications. In IOP Conference Series: Earth and Environmental Science (Vol. 469, No. 1, p. 012096). IOP Publishing.

30 Wawancara dengan Bapak Sutlan, Kepala Desa di Pantai Sembilan 
Secara prinsip pihak dinas pariwisata Sumenep mendukung konsep pariwisata syariah, namun di sisi lain pihak yang harus mendukung dan mensepakati agar konsep tersebut berjalan adalah para tokoh masyarakat di Sumenep. Berdasarkan keterangan dari pengelola wisata kurang sependapat terkait branding pariwisata syariah. Penyematan nama syariah menjadi sesuatu hal yang lebih bersifat ibadah yang seharusnya dipisahkan dengan konsep wisata, karena hal tersebut dua hal yang berbeda. Secara praktik pengelolaan yang mereka jalankan tidak bertentangan dengan syariah dan itu cukup bagi mereka tanpa harus ada nama syariah dalam branding-nya. Mereka lebih setuju menyebutnya dengan wisata berkearifan lokal.

\section{Daftar Pustaka}

A. Hamid Attamini. 1992. Teori Perundang-Undangan Indonesia, Pidato Pengukuhann Jabatan Guru Besar Tetap Fakultas Hukum UI.

Achmad Badarus Syamsi, Model Partisipasi Masyarakat dalam Penentuan Arah Kebijakan Sebagai Upaya Untuk Pengembangan Pariwisata Halal di Madura, laporan penelitian tahun 2019.

Avilliani. 2012. Kemandirian Ekonomi. UIN: Institute for Development of Economics and Finance (INDEF).

Aziz, A., \& Wardi, M. (2020, April). The Use of Information Technology among Journalists in Madura: WhatsApp applications. In IOP Conference Series: Earth and Environmental Science (Vol. 469, No. 1, p. 012096). IOP Publishing.

Bagus Octafian Abrianto, "judul Eksistensi Peraturan Desa dalam Sistem Ketatanegaraan dan Perundang-undangan di Indonesia”, Jurnal Yuridika, volume 26 No. 3

Bambang Sunggono, 1998. Metodologi Penelitian Hukum (Jakarta: PT Raja Grafindo Persada.

D. Hernawan dan G. Pratidina," Model Implementasi Kebijakan Pengembangan dalam Meningkatkan Destinasi Pariwisata di Kabupaten Bogor", Jurnal Sosial Humaniora, Vol. 6 Nomor 2. Oktober 2015.

Fahad Salim Bahammam. 2012. Panduan Wisatawan Muslim, terj. Ganna Pryadarizal Anaedi \& Syifa Annisa Jakarta: Pustaka Al-Kautsar,

Fatwa Dewan Syariah Nasional Mejelis Ulama Indonesia N0.108/DSN-MUI/X/2016 tentang Pedoman Penyelenggaraan Pariwisata Berdasarkan Prinsip Syariah.

http://sumenepkab.go.id/berita/baca/potensi-wisata-syariah-sudah-menjaditrend-dunia,

http://www.ekonomisyariah.org/id/6956/wisata-syariah-potensi-lokal-yangsiap-dikembangkan-mes-sumenep/

http://www.sumenepkab.go.id/berita/baca/wisata-pulau-gili-labak-terbaikkedua-di-awj-2019,

https://kbbi.kemdikbud.go.id/entri/nul

https://mediamadura.com/2017/03/06/mui-sumenep-ternyata-sudah-milikipedoman-pariwisata-syariah/,

https://www.medcom.id/nasional/daerah/ObzqOBeN-sepuluh-desa-dianggappaling-sukses-manfaatkan-dana-desa,

L. Steinberg. 1999. Adolescence (6th edition). New York: McGraw Hill. 
Lampiran II mengenai Peta Perwilayahan Pembangunan Destinasi Wisata dalam Peraturan Daerah Provinsi Jawa Timur Nomor 6 Tahun 2017.

Laurensius Arliman S.," Peran Investasi dalam Kebijakan Pembangunan Ekonomi Bidang Pariwisata di Provinsi Sumatera Barat", Kanun: Jurnal Ilmu Hukum, Vol. 20 Nomor 2. Agustus 2018.

M. Kamil. 2008. Pusat Budaya dan Belajar Masyarakat. Bandung: Dewa Ruchi.

Maria Farida Indrati Soeprapto. Tahun 2006. Ilmu Perundang-Undangan, Penerbit Kanisius.

Mastercard-CrescentRating Global Muslim Travel Index (GMTI) report 2019,

Mochtar Kusumaatmadja. 1995. “ Pemantapan Cita Hukum dan Asas-Asas Hukum Nasional di Masa Kini dan Masa Yang Akan Datang, Makalah Jakarta.

Muhammad Djakfar. 2017 Pariwisata Halal: Perspektif Multidimensi. Malang: UIN Maliki Press

Pemda Kab. Sumenep, 2018, Buku 1 Masterplan Smart City, Kabupaten Sumenep 2019-2028,

Peter Mahmud Marzuki, 2005. Penelitian Hukum (Jakarta: Prenada Media.

Philipus M. Hadjon. 1994. Ide Negara Hukum dalam Sistem Ketatanegaraan Republik Indonesia, makalah.

Ranggawijaya Rosidi. 1998. Pengantar Ilmu perundang-Undangan Indonesia, Penerbit Mandar Maju, Bandung.

Sinamora, B., 2002. Panduan Riset Perilaku Konsumen. Jakarta: PT Gramedia Pustaka Utama.

Soetomo. 2006. Strategi-strategi Pembangunan Masyarakat. Yogyakarta: Pustaka Pelajar.

Sugiarto, Siagian D, Sunaryanto, L S dan Oetomo, D S., 2003. Teknik Sampling (Jakarta: PT Gramedia Pustaka Utama)

Wardi, Moh. Pengembangan entrepreneurship berbasis experiential learning di pesantren Al-Amien Prenduan Sumenep dan Darul Ulum Banyuanyar Pamekasan. Diss. UIN Sunan Ampel Surabaya, 2017.

Wardi, Moh, et al. "Entrepreneurship And Financing In Islamic Educational Institution Of Darul Ulum Banyuanyar Pamekasan." Academy of Entrepreneurship Journal 25 (2019): 1-14. 